\title{
MONTRADO 1818-18588 Dinamika KOta tambang emas
}

\author{
MONTRADO IN 1818-1858: \\ DYNAMIC GOLD MINECITY
}

\author{
Any Rahmayani \\ Balai Pelestarian Nilai Budaya Pontianak \\ Jl. Letjen Sutoyo Pontianak \\ Email: any.rahmayani@yahoo.com
}

\begin{abstract}
Abstrak
Penelitian ini menyajikan gambaran Kota Montrado pada 1818-1858. Montrado, pernah menjadi salah satu pusat kongsi pertambangan emas besar di Borneo Barat. Latar belakang penelitian ini adalah keberadaan kongsi-kongsi emas di Borneo Barat yang memegang peranan penting bagi perubahan yang terjadi di wilayah ini baik ekonomi, sosial dan politik. Permasalahan pokok yang dibahas adalah gambaran Kota Montrado dan perubahan yang terjadi seiring dengan dinamika kongsi pertambangan emas. Tujuan dari penelitian ini adalah menggambarkan proses terbentuknya Montrado sebagai pusat kongsi emas dan merekonstruksi keadaan Kota Montrado pada paruh pertama abad ke-19. Metode yang digunakan adalah metode sejarah yang terdiri atas empat tahapan: heuristik, kritik, interpretasi dan historiografi. Hasil penelitian menunjukkan bahwa Kota Montrado masa kongsi merupakan kota yang lengkap dengan pusat pemerintahan, pusat perdagangan, sarana ibadah, kelengkapan infrastruktur dan sanitasi serta wilayah-wilayah pendukung. Ekologi kota ini berubah seiring dengan runtuhnya kongsi pertambangan emas yang berpusat di wilayah tersebut. Perubahan ini dapat dilihat dari berbagai sektor seperti penurunan jumlah penduduk akibat migrasi setelah perang, runtuhnya simbol-simbol kekuasaan kongsi (thang) serta perubahan dalam organisasi pemerintahan sekaligus kemasyarakatan Tionghoa yang berganti dengan sistem yang ditetapkan pemerintah kolonial.
\end{abstract}

Kata kunci: kota, kongsi pertambangan, Tionghoa.

\begin{abstract}
This study presents an overview of Montrado City between 1818 through 1858. Montrado was the major of gold mining joint venture facility in West Borneo. The background of this research is the existence of gold syndicates in West Borneo that plays an important role for the changes of economic, social and political that occurred in this region. The main problem discussed here is the image of the City of Montrado and its changes that occur in line with the dynamics of the gold mining joint venture. The aim of this study is to describe the process of formation of the joint venture Montrado as a center of gold and reconstruct the state of Montrado City in the first half of the 19th century.The method used is the historical method which consists of four stages: heuristics, criticism, interpretation and historiography. The results showed that joint venture of Montrado City was a complete city with the center of government, trade centers, places of worship, the completeness of sanitation and infrastructure. This city ecology was changed along with the collapse of the gold mining joint venture in this region. These changes can be seen from various sectors such as the decline in population due to migration after the war, the collapse of the
\end{abstract}


symbols of power of joint venture (thang) as well as changes in the organization of government in the Chinese community which is replaced by a system that defined by the colonial government.

Keywords: city, mine partnership, Chinesse.

\section{A. PENDAHULUAN}

Emas pernah begitu menyilaukan di Borneo Barat pada abad ke-19. Kejayaan, kekuasaan bahkan konflik yang begitu besar pernah melanda kawasan ini disebabkan oleh komoditi tersebut. Walaupun tidak pernah tercatat sebagai komoditas paling diunggulkan dalam perniagaan antara wilayah-wilayah Borneo Barat dengan Singapura maupun Batavia, namun emas memegang peranan penting bagi perubahan yang terjadi di wilayah ini tidak saja secara ekonomi namun juga secara sosial dan politik. Montrado, ${ }^{1}$ sebuah tempat di pedalaman Kabupaten Bengkayang Provinsi Kalimantan Barat, merupakan saksi berkilaunya emas pada masa lalu. Dalam catatan para pejabat kolonial, Montrado merupakan sebuah wilayah yang paling sering disebut-sebut sebagai bekas kota tambang besar di Borneo Barat, selain Kota Mandor dengan kongsi pertambangan emas Lanfangnya yang kuat.

Namun, bila kita datang ke Montrado, monumen kejayaan tidak akan pernah kita temui. Hanya bekas-bekas tambang emas baik yang dikelola oleh perusahan ataupun penambangan emas tanpa izin yang ada di sana beserta berbagai permasalahan lingkungan yang ditinggalkannya. Memang benar setelah kongsi pertambangan runtuh dan bahkan pada masa Republik Indonesia, emas dikelola oleh pihak-pihak lain namun tanpa meninggalkan jejak yang membawa kenangan pada kejayaan emas di masa lalu.

Terlepas dari hal itu, keadaan kota dan masyarakat pertambangan yang terbentuk nampaknya belum menjadi bagian

1 Montrado juga sering disebut Montradok dalam beberapa catatan kolonial. Berkaitan dengan status administrasinya di masa kini, nama Monterado lebih sering disebutkan oleh penduduk sekitar. tersendiri dari keseluruhan kajian tentang pertambangan emas di Borneo Barat. Kenyataan tersebut menjadikan topik ini menjadi hal yang menarik untuk dikaji selain temuan penulis secara parsial tentang fakta-fakta tentang kehidupan sosial kemasyarakatan dari masyarakat pertambangan di beberapa catatan perjalanan pejabat-pejabat kolonial ataupun pedagang-pedagang Eropa.

Dari uraian di atas yang menunjukkan perlunya kajian ini dilakukan dengan ketersediaan data yang cukup maka penulis menyusun sebuah kajian yang menitikberatkan pada tema sejarah kota dengan judul, "Montrado 1818-1858: Dinamika Kota Tambang Emas". Uraian latar belakang masalah yang telah dikemukakan di atas merupakan dasar bagi penulis untuk membahas tentang kota tambang emas Montrado dan aktivitas masyarakatnya. Berikut rumusan masalahnya (1) Bagaimana tumbuh dan berkembangnya Montrado sebagai pusat kongsi pertambangan emas? (2) Bagaimana gambaran kota dan masyarakat setelah Montrado pusat kongsi pertambangan emas sampai pada pertengahan abad ke-19 ketika kongsi tersebut runtuh?

Pembahasan akan mengambil lingkup spatial wilayah kota Montrado dan sekitarnya. Montrado berada di dalam kekuasaan Sambas. Mengenai gambaran tentang Montrado setelah masa berakhirnya kekuasaan kongsi, berikut penjelasannya. Kota Montrado merupakan sebuah wilayah yang menjadi ibukota Afdeeling Montrado sampai 1880 (Meeteren Brouwers, 1927: 1092).

Lingkup temporal penulisan dibatasi pada tahun 1818-1858 tanpa mengabaikan awal kedatangan orang Tionghoa dan cikal bakal kongsi pertambangan pada akhir abad ke-18. Tahun 1818 merupakan tahun berdirinya permukiman di Montrado 
sedangkan 1858 merupakan tahun berakhirnya kongsi emas yang membentuk Montrado sebagai pusat aktivitas tambangnya. Adapun tujuan dari penelitian ini adalah (1) menggambarkan proses terbentuknya Montrado sebagai pusat kongsi emas pada awal abad ke-19 (2) merekonstruksi keadaan Kota Montrado setelah berkembang menjadi pusat kongsi pertambangan emas sampai pada pertengahan abad ke-19 ketika kongsi tersebut runtuh.

\section{B. METODE PENELITIAN}

Sebagai sebuah kajian sejarah, tulisan ini disusun secara diakronis. Seperti kita ketahui bahwa ada empat tahap dalam metode sejarah yaitu heuristik, kritik, interpretasi dan historiografi. Heuristik sebagai tahapan pertama dengan proses menemukan dan mengumpulkan sumber. Sumber tertulis baik primer maupun sekunder didapatkan dari studi literatur. Penelusuran arsip dilakukan di ANRI (Arsip Nasional Republik Indonesia) untuk mendapatkan laporan, foto, peta/sketsa. Penelusuran di Perpusnas menemukan informasi yang tidak kalah penting yang didapatkan dalam beberapa artikel surat kabar baik nasional maupun lokal, majalah kolonial maupun jurnal (Bijdragen tot de Taal, Land en Volkenkunde van Nederlandsch-Indie, De Indische Gids, Tijdschrift Economische Geographie). Demikian pula dengan laporan baik laporan kolonial atau perjalanan yang diterbitkan seperti catatan Rees, Earl dan Buys. Buku-buku pendukung lain didapatkan dari Perpustakaan BPNB Pontianak, dan Perpustakaan Daerah Kalimantan Barat. Langkah kedua adalah kritik, baik intern dan ekstern, sebagai langkah untuk mengetahui kelayakan dan keabsahan informasi yang diperoleh. Langkah berikutnya adalah interpretasi terhadap fakta-fakta sejarah yang pada akhirnya dijalin menjadi jalinan yang kronologis dalam proses terakhir dalam penelitian yaitu historiografi.
Buku yang menjadi referensi penulis adalah Penambang Emas, Petani, dan Pedagang di "Distrik Tionghoa" Kalimantan Barat karya Mary Somers Heidhues. Tulisan ini memberikan gambaran jelas tentang Tionghoa dalam sisi kependudukan Kalimantan Barat yang berbeda dengan Tionghoa di Jawa. Selain mengulas tentang organisasi komunitas Tionghoa seperti kongsi emas, buku ini juga memberi gambaran bagaimana mereka menjaga kekhasannya sebagai upaya proteksi pada komunitasnya yang salah satunya berupa permukiman.

Berkaitan dengan masyarakat tambang yang membangun kota tersebut, tentunya unsur-unsur tumbuhnya pertambangan ini perlu dibahas secara khusus. Erwiza Erman dalam Research Trends of Indonesian Mining Hystory menyatakan pembukaan usaha pertambangan diikuti dengan terbentuknya masyarakat tambang dengan stratifikasi sosial tingkat tinggi yang berdasar pada perbedaan budaya, kepercayaan dan latar belakang pekerjaan (Erman, tt:21).

Kuntowijoyo menyatakan bahwa salah satu bidang garapan sejarah kota adalah perkembangan ekologi kota. Ekologi dapat berubah dengan adanya penggunaan tanah untuk berbagai sektor, perkembangan penduduk (secara status, kelas, kultural dan permukiman terpisah), kemajuan tehnologi, kemajuan transportasi dan perubahan dalam organisasi masyarakat. Beberapa faktor tersebut nampaknya terjadi di Montrado pada abad ke-19.

\section{HASIL DAN BAHASAN}

1. Pertambangan Emas di Montrado 1.1 Munculnya Aktifitas Tambang Emas di Montrado

Aktivitas orang Tionghoa di Borneo bagian barat berkaitan kedatangan mereka ke Borneo bagian barat melalui Laut Cina Selatan walaupun wilayah pantai di pesisir barat Borneo tidak mudah untuk dilewati. Daerah pesisir pantai tersebut lebih banyak dipenuhi karang yang menyulitkan kapal untuk berlabuh. Sementara Heidhues (2008) menyebutkan bahwa sebelum abad 
ke-13, hubungan dagang antara penduduk asli dengan orang Tionghoa bergantung pada pertukaran barang lokal seperti hasil hutan, emas dan intan dengan barang impor seperti garam, arak, pakaian di pelabuhan-pelabuhan Borneo yang berada jauh dari jalur perdagangan internasional. Keberadaan orang Tionghoa di Borneo bagian barat diperkuat dengan laporan pemerintah Inggris yang ada di Serawak hanya menyatakan bahwa orang Tionghoa telah menetap di wilayah yang mereka sebut Dutch Borneo sebelum abad ke-18 (Dutch Borneo, 1920: 11). Bersamaan ketika VOC memperkuat kedudukan di Batavia, orang-orang Tionghoa bahkan dengan bebas berdagang di jaringan perdagangan antar pulau di Nusantara. Perdagangan yang dilakukan orang-orang Tionghoa tersebut terus berkembang karena mereka bersama jung-jungnya banyak mengunjungi pelabuhan-pelabuhan yang enggan didatangi oleh VOC karena bagi VOC (dan pemerintah kolonial selanjutnya sampai pertengahan abad ke19) pelabuhan tersebut tidak memberi keuntungan yang besar (Blusse', 1988: 125).

Berkaitan dengan potensi kandungan emas di tanah Borneo Barat, Panembahan Mempawah merupakan perintis yang melakukan kerjasama dalam mendatangkan sejumlah orang Tionghoa untuk secara khusus mengelola deposit emas yang ada dalam wilayah kekuasaannya. Kedatangan mereka tercatat pada tahun 1740 dan 1745. Melihat keberhasilan penguasa tetangganya, maka Sultan Umar Akkamuddin dari Kesultanan Sambaspun mengikuti jejaknya. Setelah usahanya mendatangkan orang Tionghoa tersebut muncullah permukiman wilayah kekuasaan yaitu di Seminis dan Larah. Permukiman ketiga ditemukan di Montrado yang ternyata tanahnya banyak mengandung emas (van Meeteren Brouwer, 1927: 1057).

Izin pembukaan tambang emas berkaitan dengan penguasaan lahan, upeti dan ketentuan lain, psecara mutlak ada di tangan Sultan Sambas. Hak-hak lain yang diberikan kepada kongsi oleh Sultan Sambas kala itu, Sultan Umar Akkamaddin II, meliputi kekuasaan pemerintahan, pengadilan dan keamanan (Alqadrie, 1984: 70). Bahkan, orang-orang Tionghoa diberi bekal peralatan ataupun keperluan konsumsi dengan persyaratan bahwa orang Tionghoa harus membayarnya dalam bentuk emas (Poerwanto, 2005: 121).

Sekitar tahun 1770-1777, kongsi emas yang berada di Montrado dan sekitarnya berjumlah sebanyak 14 buah yaitu Thaikong, Lo Pat Foen, Kioe Foen Theo, Sjap Sam Foen, Kiet Lien, Sin Pat Soen, Sam Thiao Kioe, Man Fo, Sin Woek, Hang Moei, Sjip Ng Foen, Thai Fo, Lo Sjip Si Foen, Sjip Ngi Foen. ${ }^{2}$ Jumlah kongsikongsi yang ada dalam kongsi besar $F o$ Sjoen yang kemudian dikenal dengan $F o$ Sjoen Tjoengthang terus berkurang dari waktu ke waktu. Pada tahun 1807 menjadi duabelas kongsi dan tahun 1808 menjadi empat kongsi (Engelhard, 1899: 243). ${ }^{3}$ Dari sekian banyak kongsi yang ada di kongsi Fo Sjoen, kongsi Thaikong (yang berarti pelabuhan/ sungai besar) merupakan yang terbesar dan terkuat. Bahkan dapat dikatakan Thaikong mengambil alih kekuasaan Fo Sjoen dan berjaya pada awal sampai pertengahan abad ke-19.

\subsection{Organisasi pada \\ Kongsi Pertambangan Emas}

Dalam organisasi kongsi, seluruh anggota kongsi adalah pemegang saham, baik pekerja, pengusaha maupun

2 Kelompok kongsi-kongsi ini membentuk kongsi besar atau yang disebut oleh Heidhues sebagai "federasi" bernama Fo Sjoen. Sampai pada tahun 1780 tercatat tiga kongsi emas besar yang ada di Borneo bagian barat, selain Fo Sjoen yaitu Kongsi yang berada di Larah, Kongsi Lim Thian yang berada di Budok, Kongsi Lan Fong di Mandor (Van Meeteren Brouwers, 1927: 1060).

\footnotetext{
${ }^{3}$ Walaupun pada tahun 1825 pernah meningkat menjadi lima kongsi.
} 
pedagang. Kongsi-kongsi ini biasanya akan bergabung dalam sebuah kongsi yang lebih besar. Berikut penjelasan tentang konsep kongsi yang ada di Borneo bagian barat sehingga kemudian disebut sebagai "republik.". Kelompok orang Tionghoa yang membentuk kongsi tidak selalu berasal dari desa yang sama namun adakalanya berasal dari desa-desa yang berbeda. Masing-masing dari mereka dipimpin oleh lo-thai. Selanjutnya secara bersama mereka memilih pemimpin kongsi yaitu kap-thai sebagai hakim dan pimpinan distrik yaitu kapitan. ${ }^{4}$ Masa berkuasa para pemimpin adalah dua tahun, namun jika dipilih kembali dapat berkuasa selama dua periode atau lebih. Pemilihan pemimpin akan dilakukan apabila pemimpin lama tidak dapat lagi menjalankan tugas karena mengundurkan diri (karena masa kepemimpinannya telah habis atau karena sebab lain), meninggal atau berpindah. Selain itu terdapat sebuah dewan yang memutuskan perkara-perkara serius. Kantor dewan dan tempat pertemuan berada di thang, balai kota dan kuil kematian. Perkara mereka bicarakan secara terbuka (Vleming, 1926: 256). Sampai di sini, kita dapat melihat sisi demokratis dari kongsi.

Kongsi besar membawahi kongsikongsi kecil sekaligus kampung-kampung yang ada di sekitarnya. Kampung tersebut dipimpin oleh seorang kungse (sebagaimana yang ditemui Earl pada kunjungan pertamanya di Singkawang). Mereka memiliki kekuasaan peradilan di wilayahnya sehingga dapat memutuskan perkara yang dihadapi kecuali perkara yang besar. Setiap kungse juga memiliki seorang juru tulis. Selanjutnya, pimpinan kongsi besar memiliki kekuasaan atas wilayah, menyelesaikan masalah perdata dan pidana (seperti telah dikemukakan di atas mereka memiliki dewan untuk

\footnotetext{
${ }^{4}$ Bentuk kekuasaan Kongsi Lanfang di Mandor yaitu tai-ko (abang paling besar), nyi-ko (abang kedua), kaptai (kapten besar) yang dibantu kap tjong, dan lo-thai (kepala kampung) (Lontaan, 1975: 250).
}

memutuskan perkara), menjaga kesiapan angkatan bersenjata, pengembangan jalur hubungan komunikasi darat (membangun jalan), mengembangkan perniagaan, memungut pajak, mencetak uang logam, mendirikan sekolah dan menyelenggarakan upacara keagamaan (Heidhues, 2008: 50).

Kongsi besar menjalankan pemerintahan dengan organisasi yang cukup matang. Setidaknya begitulah yang terlihat di masa ketika Kongsi Thaikong menguasai Montrado. Kerja dari pimpinan kongsi dibantu oleh beberapa pegawai yaitu (1) Fotjong atau pengawas, yang melakukan pengawasan terhadap para pekerja tambang, mengatur jam kerja, dan mengatur subsidi air melalui waterleiding (2) Juru tulis atau administrator, mengurusi pembukuan keuangan, membeli semua kebutuhan untuk perlengkapan, dan melakukan korespondensi.Veth menyebutkan terdapat dua juru tulis yang mengurus keuangan dan urusan rumah tangga serta menyimpan barang (Veth, 2012: 269, 282) (3) Tseu koy, sebuah pangkat pimpinan yang terendah, biasanya para pekerja yang kuat, sering disebut mandor (Rees, 1858: 81-82). Secara profesional, kongsi membayar para pegawainya dengan teratur. Rata-rata seorang fotjong dan juru tulis mendapatkan f. 16 sampai $f .20$ per bulan. Sedangkan seorang tseu koy mendapatkan $f$. 14 sampai f. 16 per bulan (Rees, 1858: 83). Sedangkan kuli di pertambangan ini dibayar dengan upah yang setara dengan $f$. 0,75 sampai $f$. 0,80 per hari dan bebas dari biaya perumahan (Engelhard, 1899: 256).

Transaksi dengan pedagang dari luar dilaksanakan di pusat Kota Montrado. Kedatangan mereka ke Montrado dibantu oleh para bawahan ketua kongsi yang ada di Singkawang. Earl seorang pedagang Inggris dari Singapura, disambut oleh ketua kongsi dan para bawahannya di pintu courtyard. Para tamu akan disambut dengan 3 tembakan penghormatan. Transaksi dengan orang asing dilakukan dengan perantara dari penterjemah karena ketua kongsi tidak dapat berbahasa Melayu 
sekalipun. Ketua kongsi (Earl menyebutnya Gubernur) akan memutuskan perniagaan dengan orang asing akan dilanjutkan atau tidak setelah berdiskusi dengan para kungse (Earl, 1837: 285).

\subsection{Konflik-konflik yang Melibatkan Pusat Kongsi Montrado}

Sepuluh tahun pertama keberadaan pekerja Tionghoa di lokasi pertambangan merupakan periode yang "baik-baik saja". Namun kemudian muncul rasa tertindas dari para pekerja Tionghoa dimana mereka merasa diperlakukan secara kejam oleh para pengawas-pengawas serta pendapatan mereka yang terus menurun akibat dari upeti yang diwajibkan oleh pengusa Melayu (van Meeteren Brouwers, 1927: 1058). Selain itu perebutan lahan emas dan sungai sering menjadi faktor penyebab pertikaian antar kongsi. Sampai tahap ini, satu hal yang kemudian sangat berpengaruh pada kelangsungan kongsi pertambangan yaitu intervensi pemerintah kolonial terhadap Montrado. Sesampainya di Borneo Barat pada tahun 1818, pemerintah kolonial segera tertarik pada keberadaan orang-orang Tionghoa pusatpusat kongsi. Mereka merasa perlu menundukkan orang-orang Tionghoa di bawah kekuasaan pemerintahannya. Oleh karenanya, setelah menancapkan kekuasaan di Sambas, pemerintah kolonial, dalam hal ini asisten residen Sambas, Muller, segera menuju Montrado yang secara hukum berada di wilayah Kesultanan Sambas. Orang Tionghoa di Montrado kemudian diikat dengan peraturan yang ditetapkan pada 4 Februari 1819 yang menetapkan bahwa setiap orang Tionghoa berusia lebih dari 16 tahun diwajibkan membayar pajak kepala setiap tahunnya yang dapat dicicil selama 4 kali (Meeteren Brouwer, 1927)

Konfik pertama adalah konflik antar kongsi yang berkembang menjadi konflik antara kongsi melawan kongsi lain yang bekerjasama dengan pemerintah kolonial sampai akhirnya konflik antara kongsi dan pemerintah kolonial. Pertikaian antar kongsi dalam satu kongsi besar terlihat pada tahun 1807 dimana terjadi perselisihan antara Thaikong dan sekutunya melawan kongsi Kit Lien dan sekutunya. Perselisihan ini dimenangkan oleh Thaikong. Perselisihan ini berlanjut pada tahun 1808. Kali ini Thaikong berselisih dengan Sin Pat Foen (sekutu dari Kit Lien) akibat dari perebutan lahan tambang dan pembagian air yang dianggap tidak adil. Thaikong dibantu oleh Tjoe Foeng $\mathrm{Fa}^{5}$ dari kongsi Samtiakiou. Akibat dari pertikaian ini lahan tambang di wilayah ini dibagi antara Thaikong, Hang Moi dan Sin Woek (Meeteren Brouwers, 1927: 1060-1061). Akibat perselisihan tersebut anggota Kongsi Besar Fo Sjoen yang tersisa berjumlah tujuh kongsi yaitu Thai Kong, Samtiaukiu, Man Fo, Hang Mou, Sin Wok, Sjip Ng Foen dan That Fo.

Periode Perang Kongsi 1822-1824 merupakan perang terbuka antara dua kongsi anggota kongsi besar Foesjoen yang pada saat itu mengalami penurunan deposit emas dari seluruh lahan tambangnya, yaitu Samtiaokioe dan Thaikong. Seusai perang ini, pemerintah kolonial membagi lahan emas di mana Thaikong mendapatkan lahan di Montrado dan Sungai Raya sedangkan Samtiaokioe mendapat lahan di bagian utara Montrado. Sampai tahun 1837 hanya tersisa kongsi Thaikong di Montrado.

Bentuk konflik selanjutnya adalah konflik antar kongsi dan kelompok Dayak. Heidhues memperlihatkan konflik yang terjadi pada 1842 ketika para penambang Tionghoa merebut tambang emas Dayak di Lara. Bentuk konflik menjadi berkembang antara pasukan gabungan kongsi Thaikong ${ }^{6}$ dan Dayak di Selakau dengan pasukan gabungan Dayak yang dikerahkan oleh pejabat kerajaan Sambas (Heidhues, 2008: 77).

\footnotetext{
${ }^{5}$ Ia nantinya dikenal sebagai Kapitan Sin Sang yang menjadi pimpinan kongsi di Montrado pada tahun 1819-1820.

${ }^{6}$ Orang Tionghoa yang merebut tambang emas Dayak di larah berasal dari Kongsi Thaikong.
} 
Periode perang selanjutnya adalah tahun 1850-1854. Kali ini disebabkan oleh beberapa faktor yang dapat kita lihat dari beberapa peristiwa. Mari kita mulai dari yang pertama. Kebutuhan candu, garam dan barang kebutuhan lain yang hanya didapatkan dari luar Borneo ternyata menjadi sebab tidak langsung dari perang kongsi yang terjadi lagi di pertengahan abad ke-19. Perselisihan Thaikong dengan kongsi lain serta penguasa Melayu yang akhirnya menyeret intervensi pemerintah kolonial menyebabkan kongsi ini merasa perlu dan penting untuk menambah persenjataan. Kebutuhan ini hanya bisa didapatkan dalam jumlah yang tidak terbatas tanpa melewati regulasi penguasa atau dengan kata lain mendatangkan dengan jalan penyelundupan. Pendapatan Kesultanan Sambas atas bea barang-barang imporpun semakin berkurang karenanya. Oleh karena itu, pada 1849, kerabat istana Sambaspun meminta bantuan pada Belanda untuk menanggulanginya. Beberapa kali pemerintah kolonial berhasil menggagalkan penyelundupan garam, opium dan serbuk mesiu yang akan dikirim ke Montrado di Sedau (Heidhues, 2008: 83). Kedua, perang tahun 1850-1854 merupakan eskalasi dari berbagai pertikaian setelah perang kongsi pertama. Pertikaian Thaikong dan Samtiaokiou terus berlanjut. Pada perselisihan ini, Samtiaoukiou mendapatkan bantuan dari Kesultanan Sambas dan pemerintah kolonial. Ketakutan Samtiaokiou dikarenakan beberapa hal yaitu kekuatan pasukan Thaikong lebih banyak dan bergabungnya kongsi-kongsi di Lumar dan Buduk dengan Thaikong. Berkurangnya anggota kongsi Foesjoen berarti berkurangnya lahan emas bagi Thaikong, yang nantinya akhirnya menjadi satusatunya anggota Foesjoen. Perang pada periode ini cukup memberikan perubahan yang berarti bagi kongsi-kongsi emas. Pemerintah kolonial bahkan membentuk sebuah administrasi regent di wilayah yang dikuasai Foesjoen untuk menandingi Thaikong. ${ }^{7}$ Periode ini diakhiri dengan dihapuskannya organisasi kongsi emas yang ada di wilayah ini pada akhir tahun 1854. Akibatnya, terjadi migrasi pekerja tambang dalam skala yang relatif besar ke daerah pesisir pantai dan lembah-lembah sungai besar.

Pada tahun 1854 (di masa ketika Perang Kongsi berkecamuk antara pasukan tentara kolonial dan pasukan kongsi-kongsi Tionghoa), Singkawang dan sekitarnya termasuk Pajintan, Sei Raya, Sungai Doeri, Montrado dan Koelor dikuasai oleh militer dan otoritas pimpinan distrik Tionghoa tersebut diambilalih oleh pegawai gubernemen (Van Meteeren Brouwers, 1927: 1085). Penghapusan kongsi secara nyata ditandai dengan sebuah upacara yang dilangsungkan di balai utama di Montrado. Selanjutnya penguasa Sambas memberikan kompensasi berupa penyerahan hak pajak pertambangan milik orang Tionghoa kepada pemerintah kolonial atas bantuannya menumpas pemberontakan para penambang. Tambang emas dikuasai pemerintah dan kemudian disewakan melalui sistem pacht $^{8}$ dengan terbitnya pengumuman dari Letnan Kolonel Andersen, atas nama Residen Borneo Barat, pada 15 Januari 1855 (Engelhard, 1899: 252). Secara politis, wilayahwilayah kongsi pertambangan Montrado yang berhasil dilumpuhkan oleh pasukan Belanda kini berada di wilayah kekuasaan kepembanturesidenan (de assistantresidentie) Montrado.

Kekuasaan penuh pemerintah kolonial di wilayah ini ditandai dengan berlakunya pajak kepala kepada setiap laki-laki sejumlah 3 gulden. Pajak ini merupakan persyaratan untuk mendapatkan kartu

\footnotetext{
${ }^{7}$ Baca Heidhues, 2008 pada bab "Dari Tahun 1850 Sampai Kehancuran Kongsi”

${ }^{8}$ Pachter adalah orang yang oleh pemerintah kolonial ditetapkan sebagai pemegang hak sewa. Perhitungan sewa tergantung pada hasil tambang (atas kesepakatan pekerja tambang dan pachter sendiri memiliki standar atau perkiraan harga emas (Engelhard, 1899: 253)
} 
identitas yang menunjukkan bahwa ia bukanlah anggota dari pemberontak (Heidhues, 2008: 98). Kerja paksa juga diterapkan untuk para laki-laki sekali dalam satu minggu untuk membangun jalan antara Singkawang sampai Montrado. Kebijakan wijkenstelsel diterapkan bagi penduduk Montrado di mana mereka harus tinggal di permukiman terpusat seperti pasar dan kampung Tionghoa.

\section{Pusat Kota Montrado \\ 2.1 Permukiman Tionghoa di Kota Montrado}

Sebagaimana telah disebutkan pada bagian sebelumnya bahwa permukiman di Montrado merupakan permukiman Tionghoa ketiga di wilayah Kesultanan Sambas, setelah permukiman Tionghoa di Seminis dan Larah. Lebih rinci lagi bahwa tiga tahun setelah kedatangan mereka ditemukan 24 komunitas di Montrado yang kebanyakan adalah pan san hok (Meeteren Brouwer, 1927: 1057). Pan san hok secara harfiah diartikan sebagai orang setengah gunung. Hal ini menunjukkan sebuah interaksi antara kelompok bahasa Hakka (Khek) dari pedalaman Tiongkok dengan kelompok bahasa Teochiu dari pesisir selatan Tiongkok dan akhirnya membentuk sebuah kelompok yang berbahasa setengah Teochiu dan setengah Hakka (Heidhues dalam Rahmayani, 2011: 15).

Montrado yang berada di timur laut Singkawang (yang merupakan pintu masuk ke Montrado dari Laut Cina Selatan) merupakan kota di mana thang atau balai besar kongsi berada. Untuk mencapai Montrado, perjalanan dari Singkawang dimulai dengan melewati pemukimanpemukiman petani baik di lembah maupun bukit-bukit menuju Montrado. Para petani inilah yang menyediakan bahan makanan untuk kebutuhan kongsi walaupun kongsi tersebut tidak sepenuhnya bergantung padanya. Permukiman petani ini dipenuhi dengan rumah-rumah yang dibangun dengan dinding bata yang tidak dibakar dan beratap alang-alang serta dikelilingi pohon buah-buahan (Earl, 1837: 281).
Montrado juga digambarkan oleh George Winshor Earl yang mendatangi kota itu pada tahun 1834. Montrado merupakan sebuah kota yang terdiri dari sebuah jalan tunggal dengan 3 perempatan. Sebuah rumah dari petinggi pertambangan (gubernur kongsi) berdiri terpisah dari permukiman dan terlihat lebih besar ukurannya daripada yang lain serta dilengkapi dengan pepohonan besar. Keadaan pusat pertambangan Montrado digambarkan Rees sebagai sebuah tempat tinggal yang sangat nyaman dengan tanah yang subur yang dikelilingi bukit-bukit (Rees, 1858: 37).

Kota Montrado berada di bagian utara dari sebuah danau, yang orang-orang menyebutnya dengan istilah Dayak pagong, sebuah penampungan air tambang atau danau buatan yang airnya diperoleh dari membendung sungai. Air danau buatan ini diperlukan untuk "mencuci" tanah yang mengandung emas pada proses penambangan.

Sebuah balai utama, thang, yang juga merupakan lambang supremasi kongsi pertambangan emas berdiri agak jauh dari permukiman. Thang berfungsi sebagai balai utama untuk transaksi, ruang penyambutan tamu serta sebagai rumah ibadah (thai pak kung) utama bagi para anggota kongsi (Rahmayani, 2010: 43). Thang adalah bangunan balai pertama yang didirikan di Montrado (Rees, 1858: 36). Bangunan ini memiliki konstruksi yang kokoh dengan kayu ulin (kayu besi), beratap sirap dan dibentengi dengan benteng tanah. Di dalam benteng tersebut terdapat halaman, aula tengah dan altar, kamar-kamar besar untuk ketua kongsi, keluarga dan juru tulisnya serta tempat penyimpanan peralatan sembahyang dan arsip (Rees, 1858: 37).

Di sisi lain, berjarak masing-masing limabelas menit berjalan, terdapat bangunan Sjongbok dan Habok. Sjongbok merupakan balai kedua yang dibangun setelah Thang dan selanjutnya Habok sebagai bangunan terakhir. Rees menyebut Sjong bok sebagai "rumah tinggi" dan 
Habok sebagai "rumah rendah" (Rees, 1858: 37). Heidhues memperkirakan Habok adalah rumah kongsi Samtiaokiu ketika masih berada dalam naungan kongsi besar Fo-Sjoen sedangkan Sjongbok adalah rumah kongsi Thaikong yang baru (Heidhues, 2008: 91).

Seperti halnya Thang, Sjongbok juga dibangun dengan kayu besi dan memiliki halaman. Perbedaannya adalah bentuk aula dimana untuk menaiki aula Sjongbok harus menaiki beberapa anak tangga. Sebuah pintu yang tertutup menghadap ke halaman yang berbentuk persegi. Setelah memasuki aula yang besar akan terlihat kertas-kertas inskripsi, lentera dan lilin yang menghiasi altar serta rak senjata (Rees, 1858: 38-39). Di samping kiri dan kanan bangunan utama terdapat dua rumah lain yang menjadi tempat tinggal bagi para penambang emas. Setelah perang kongsi, salah satu dari dua rumah tersebut yang diperbarui dengan kayu besi dan bambu ini difungsikan sebagai rumah sakit sedang yang lainnya dibuat dari blok tanah liat dan dipergunakan untuk barak bagi pasukan (Rees, 1858: 39).

Adapun Habok, terlihat lebih sederhana dari dua bangunan sebelumnya. Habok hanya memiliki benteng, sebuah rumah kepala kongsi dan bangunan tambahan dari tanah liat serta sebuah pipa air (Rees, 1858: 40). Keadaan permukiman di Montrado diperjelas dengan denah berikut.
Gambar 1 Statte Grond van Mondrato (Wilayah
Kota Mondrato/ Montrado) ${ }^{9}$

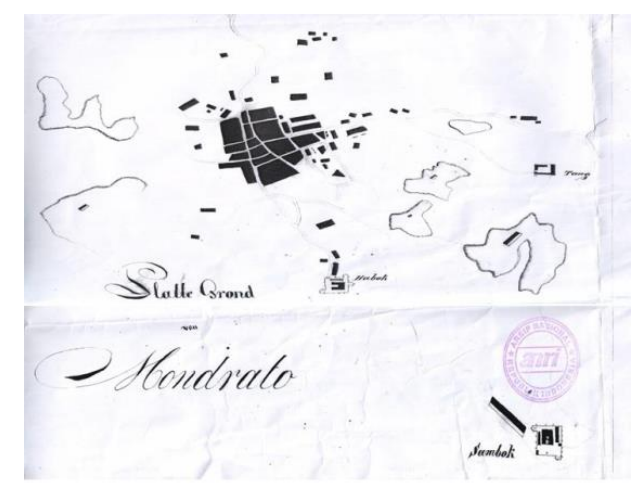

Sumber: ANRI

Jika ditarik garis lurus, komplek thang, habok dan sjongbok (tertulis di sketsa sebagai sambok) membentuk garis segitiga. Thang yang merupakan lambang kekuasaan kongsi kepala pemerintahan. Isu politik, hukum dan pengambilan keputusan untuk kepentingan umum diputuskan di tempat ini (Rees, 1858: 38). Oleh karena itu, pada masa Perang Kongsi, thang sengaja dibakar oleh Kongsi Samtiaokiu dan pasukan Belanda untuk melemahkan Kongsi Thaikong. Sedangkan fungsi habok dan sjongbok setelah Perang Kongsi hanyalah sebagai aula atau tempat perdagangan tanpa kewenangan politik dan hukum sebagaimana dimiliki thang. Namun fungsi religius masih melekat pada dua bangunan tersebut. Masing-masing

\footnotetext{
9 Berdasarkan catatan bahwa pemerintah Hindia Belanda mulai intensif melakukan intervensi pada paruh pertama abad ke-19 (dengan memberi bantuan pada kongsi Sam Tiau Kiu, yang melepaskan diri dari kongsi Foesjoen, pada saat berperang melawan Thaikong) serta mulainya perseteruan langsung dengan kongsi Taikong sebagai kongsi terbesar di Montrado pada tahun 1849 (dengan dalih penertiban perdagangan candu) serta pengesahan Sambok dan Habok sebagai badan komersial maka penulis memperkirakan gambar diatas dibuat pada pertengahan abad ke-19 sekitar 1949-1854 . Van Meeteren Brouwer yang menyebutkan 3 rumah kongsi: thang, songwoek, hawoek (van Meeteren Brouwer, 1926: 1085).
} 
bangunan memiliki tempat untuk meramal dan peramal yang berhubungan dengan dewa yang memberikan keberkahan. Peramal dari Sjongbok berhubungan dengan Sam Bok Jak (tiga dewa utama yang dihormati penduduk Montrado) dan peramal Habok untuk dewa Moa Njong (Heidhues, 2008: 124).

Kota Montrado pada pertengahan abad ke-19 masih terlihat sebagai sebuah kampung Tionghoa dilengkapi dengan tiga buah rumah kongsi sebagaimana pada paruh pertama abad ke-19. Veth dalam Encyclopedie van Nederlandsch Indie 1918 menggambarkan kota ini sebagai sebuah kota kecil. Kota ini memiliki rumah utama yang besar dan tiga rumah kongsi yaitu thang, sjongbok dan habok. Di tengah dari tiga bangunan ini adalah sebuah pabrik penyulingan arak Tjoelong. Pabrik arak ini dibangun dengan kayu besi dan beratap sirap dan dilindungi oleh tanaman buah disekelilingnya. Pabrik arak ini juga harus membayar pungutan/ pajak kepada kongsi besar (Veth, 2012: 283).

Pasar sebagai pusat kota tergambar sebagai dua sisi jalan utama ditempati oleh pedagang dan pengrajin/tukang-tukang. Rumah mereka rendah dibangun dengan papan kayu dan tanah liat sedangkan atap terbuat dari daun rumbia atau sirap kayu ulin. Kayu yang digunakan untuk mendirikan rumah adalah kayu ulin. Rumah dilengkapi dengan parapet, dipasangi palisade (deretan rapat tonggaktonggak runcing) dan benteng. Dinding bagian dalam menggunakan tanah liat di rumah tersebut digunakan untuk perlindungan terhadap bahaya kebakaran (Rees, 1858: 43-44). Dua sisi jalan yang sejajar ini dipenuhi oleh pedagang dan pengrajin, rumah-rumah yang penuh sesak dan permukiman ini dikelilingi oleh permukiman terpisah milik petani dan peternak dan berpenduduk sekitar 50007000 jiwa. Terdapat 6-7 pasak kayu di dekat pintu dan jendela. Atap dari sirap juga menutupi bagian depan rumah sehingga pejalan kaki dapat berteduh di depannya jika hujan (Rees, 1858: 43-44).
Rumah mereka sempit dengan pintu bagian depan dari kayu berat, yang juga berfungsi untuk menempatkan barang dagangan. Bagian rumah terbagi menjadi bagian serambi depan rumah digunakan sebagai toko, ruang tamu dan ruang makan, selanjutnya kamar tidur di bagian belakang untuk seluruh anggota keluarga dan paling belakang adalah dapur dan sumur (Rees, 1858: 44). Setiap rumah terdapat kertas sesaji berwarna, sebagaimana di atas pintu diberi kertas berwarna orange yang masing-masing berisi mantra (Rees, 1858:45).

Setiap rumah memiliki tempat berdagang atau toko pada bagian depan. Salah satu rumah dalam permukiman tersebut berfungsi sebagai rumah opium yang selalu ramai dikunjungi penghisap opium. Rumah-rumah tersebut dihuni oleh pembuat obat, tabib ataupun peramal (Veth, 1869: 530). Secara detail, van Prehn mendapatkan catatan dari seorang pengunjung Montrado pada tahun 1851 bahwa di sana terdapat empat pandai besi, lima pandai emas, dua pandai timah, delapan pembuat roti/ mantau, 10 penjagal babi, lima puluh penjual ikan, empat tukang kayu, delapan puluh tukang cukur dan tukang jahit, tiga pembuat lentera dan empat guru (Heidhues, 2008: 58). Tokotoko di sana menjual beraneka ragam barang dagangan. Keperluan pemujaan sangat lengkap ditemukan dari kertas pemujaan, setanggi (stik kecil yang diatasnya terdapat dupa), tempat berlapis emas dan peralatan lain untuk menghormati dewa. Penjual jasa cukur banyak terdapat di sana. Begitu juga rumah-rumah judi. Penjual bahan makanan, sayur dan buah, tukang emas dan tukang kayu terlihat di pasar tersebut (Rees, 1858: 45).

Aktivitas peternakan dan pertanian sebagai aktivitas non tambang terlihat dari banyaknya kandang babi berada di sekitar pasar (Rees, 1858: 45). Penduduk Montrado dan daerah sekitarnya bekerja sebagai pekebun. Mereka menanam bahan pangan kebutuhan sehari-hari seperti sayur 
dan buah-buahan (Veth, 1869: 530). Beberapa klenteng juga tampak di sana.

\subsection{Sistem Birokrasi}

Penduduk Montrado dikepalai oleh pimpinan dari kelompok asal mereka di Tiongkok. Earl menggambarkan mereka memiliki kulit gelap seperti orang Melayu dan berbadan kecil. Masyarakat yang terbangun di Kota Montrado cenderung lebih bebas untuk menyusun bentuk pemerintahan Mereka bebas mengadopsi pola yang sesuai dengan situasi yang mereka hadapi. Wilayah mereka terbagi dalam beberapa distrik yang diatur oleh beberapa wakil yang disebut kung se yang dipilih oleh seluruh penduduk kota. ${ }^{10}$ Para kung se kemudian memilih gubernur. Wewenang seorang gubernur memiliki batas dimana bertugas untuk mengatur seluruh urusan yang terjadi di wilayahnya, baik domestik maupun asing, namun untuk transaksi bisnis yang penting ia harus berkonsultasi pada kung se. Baik kung se maupun gubernur memiliki kekuasaan kehakiman di wilayah teritorial masingmasing (Earl, 1837:290-291). Rees menyebut gubernur tersebut sebagai kapthay. Kap-thay memiliki hak prerogatif untuk menunjuk kepala pasar maupun kepala kampung (yang ditunjuk berdasarkan besarnya wilayah (Rees, 1958: 76-77).

Bidang hukum dan peradilan merupakan bidang yang sangat diperhatikan oleh pimpinan kongsi untuk menjaga stabilitas kongsi serta kesetiaan pekerja dan penduduk. Mari kita lihat beberapa aturan hukum yang dijalankan di Montrado ${ }^{11}$ :

1. Seseorang yang melakukan penyerangan akan diambil haknya, dipotong telinganya serta tidak diperbolehkan berada dalam kongsi

2. Pada kasus perampokan diterapkan hukuman mati. Pada kasus pencurian,

\footnotetext{
${ }^{10}$ Setiap distrik biasanya memiliki lima Kung $\mathrm{Se}$

${ }^{11}$ Aturan ini dicatat Rees dalam"Montrado", 1858.
}

hukuman potong telinga tidak akan diterapkan jika barang dikembalikan. Untuk kasus pencurian dengan skala kecil, pencuri akan dicambuk dan jika diulangi akan dijatuhi hukuman potong telinga. Pencurian di waktu kerja tanpa ampun akan dibunuh.

3. pencurian di thai pak kung dikenai hukuman pukulan rotan dan potong telinga

4. berada di malam hari di dekat tambang emas akan dihukum mati

5. jika bawahan menyerang atasannya maka akan dikenai hukuman cambuk

6. orang yang membuat orang lain cidera dalam pertempuran menanggung pengobatan dari tabib, dan jika kemudian orang tersebut meninggal dunia maka dikenai denda 10 thail emas atau f. 20.00 untuk memenuhi kebutuhan keluarga terbunuh

7. Dalam kasus pembunuhan, pelaku harus membayar biaya pemakaman korban tewas

8. Pemilik rumah yang terbakar akan dihukum cambuk rotan atas kecerobohannya. Untuk kasus kebakaran yang lebih besar pelaku dapat diberikan hukuman mati

9. Hukuman untuk pemalsuan naskah sama dengan hukuman pada kasus pencurian

10. Anak-anak perempuan diwajibkan belajar rumah sampai mereka meninggalkan rumah (untuk menikah).

11. Pelaku pemerkosaan akan dihukum keluar dari kongsi atau hukuman mati

12. Dalam pernikahan seorang istri harus tunduk dan mengikuti suami kemanapun ia pergi dan seorang suami tidak boleh menganiaya istrinya

13. Seorang perempuan tidak boleh berzinah (kecuali atas persetujuan suaminya). Jika hal tersebut dilakukan maka kedua pelaku akan dibunuh

14. Jika seorang perempuan meracuni suaminya hingga tewas (biasanya karena terjadi perselingkuhan) maka ia akan dikubur hidup-hidup. 
Formasi kepemimpinan ini kemudian berubah setelah Belanda menguasai sepenuhnya wilayah Montrado di pertengahan abad ke-19 bersamaan dengan melemahnya kekuatan Thaikong. Seorang dengan pangkat Kapthai diangkat sebagai regent yang bertanggungjawab langsung kepada Asisten Residen Sambas. Kandidat-kandidat kaptai diajukan oleh anggota kongsi dan dipilih oleh pemerintah kolonial. Kapthai pertama yang diangkat oleh pemerintah kolonial adalah Tjang Ping. Sedangkan kelompok-kelompok kecil yang berada di bawah Montrado akan dipimpin oleh lo thay. ${ }^{12}$

\subsection{Penduduk}

Penduduk yang mendiami Montrado diperkirakan sekitar 5000-7000 jiwa (Veth, 1869: 530). Jumlah ini diperkirakan lebih banyak dari penduduk yang bermukim di Singkawang ketika itu.

Wanita di Montrado lebih ramah dan penuh perhatian dengan orang asing dibandingkan kaum laki-laki. Mereka digambarkan sebagai wanita dengan penampilan petani yang kuat yang menggunakan celana panjang, kebaya panjang dari bahan katun berwarna biru, dan tutup kepala ${ }^{13}$ jerami yang lebar sehingga dapat melindungi tubuh mereka dari sengatan matahari ataupun derasnya hujan (Buys, 1892 : 173). Sedangkan kaum laki-laki dapat digolongkan sebagai pekerja keras. Laki-laki biasanya mempersenjatai dirinya dengan tombak, pedang, belati dan pistol (Rees, 1858: 70). Namun yang banyak disoroti adalah kesukaan mereka terhadap opium. Bahkan walaupun opium adalah barang yang mahal namun kelas buruh rendahanpun berlomba untuk mendapatkannya. Bahkan di masa Perang Kongsi, penyelundupan opium masih terjadi bersama dengan

12 Lo thay tetap diangkat dengan sistem pemilihan.

${ }^{13}$ Penutup kepala ini berbeda dengan milik pria di sana yang berujung lancip dan biasa disebut tudung. penyelundupan garam dan senjata melalui jaringan kongsi di Sungai Duri (Wati, 1989: 168). Keberadaan opium sebagai alat hiburan pekerja tambang didukung oleh catatan Rees yang menyatakan bahwa dari 10 rumah yang berderet di pasar dapat dipastikan ada satu penjual opium di sana dengan arus pengunjung yang besar. Untuk itu kongsi besar memungut pajak untuk setiap rumah opium sebesar f. 10 per bulan. Setiap jamnya pasti ada orang yang keluar dari sana dengan mata sendu, badan kurus dan sakit-sakitan (Rees, 1858: 44).

\subsection{Wilayah-Wilayah Pendukung}

Wilayah-wilayah pendukung yang dimaksudkan penulis disini adalah wilayah di sekitar Montrado yang mendukung kehidupan di Montrado baik yang berkaitan dengan aktivitas perniagaan hasil emas atau aktivitas untuk pemenuhan kebutuhan sehari-hari.

Pemangkat, walaupun posisinya cenderung jauh dibanding kampungkampung lainnya (karena wilayahnya di pesisir), menjadi sangat berarti bagi Montrado dikarenakan pemenuhan beras dan ikan berasal dari tempat ini. (Veth, 2012: 93). Sawah yang dikelola oleh sebagian besar orang Tionghoa di Pemangkat dan sekitarnya adalah sumber utama pemenuhan beras bagi pusat kongsi pertambangan di Montrado. Pusat kota Pemangkat memiliki karakter sebagaimana pasar sekaligus permukiman (wijken winkel) bagi orang Tionghoa. Begitupula dengan produk niaganya seperti kain, bahan kebutuhan sehari-hari, buah dan ikan (Rahmayani, 2010: 48). Walaupun sebagian besar penduduknya adalah orang Tionghoa namun kampung Bugis dan Melayu tampak berdampingan secara damai dengan kampung Tionghoa.

Singkawang memiliki kelengkapan yang dapat dikatakan sempurna bagi pusat kongsi pertambangan emas di Montrado. Oleh karena Singkawang dikatakan sebagai kota satelit bagi Montrado. Pelabuhan di Singkawang menjadi jalur utama kapal-kapal dari dan ke Singapura. 
Bahkan ketika terlibat perang yang mengakibatkan pasokan beras Montrado berkurang, Kongsi Thaikong di Montrado mendatangkan 12.000 pikul beras dari Singapura (Purwanto dalam Rahmayani, 2010: 63). Selain pelabuhan, permukiman nelayan di Sedau (bagian selatan Singkawang) juga memasok kebutuhan ikan bagi pusat kongsi di Montrado. Pada pertengahan hingga akhir abad ke-19 ketika Montrado telah melewati masa kejayaannya, Singkawang menjadi tujuan utama orang-orang Tionghoa dari pedalaman yang terusir dan melarikan diri.

Kampung Kulor, kampung pertama yang dilalui dalam perjalanan dari Singkawang menuju ke Montrado. Sebuah tambang emas kecil berdiri di kampung ini. Berada di sebuah bukit dan lembah, penduduk Kulor juga mengusahakan pertanian terutama sayur mayur yang juga dikirimkan ke Montrado. Kampung ini terdiri sekitar tigapuluhan rumah dan satu rumah kongsi di ujungnya (Veth, 2012: 99). Kulor yang berada di sebelah timur Singkawang yang menjadi tempat pemberhentian bagi orang-orang yang melakukan perjalanan antara Singkawang dan Montrado. Demi mendukung sistem pertanian mereka, petani di Kulor sempat membangun waterleiding (saluran air) besar pada masa kejayaan kongsi (sebelum 1850an). Setelah Perang Kongsi 1854, saluran air ini tidak digunakan kembali karena diblokir dan baru dibuka kembali pada 1892 (Engelhard, 1899: 261-262).

Patengahan atau sering disebut Tengahan, adalah kampung kedua yang ditemui setelah Kulor. Sebagaimana Kulor, kampung ini juga memiliki beberapa tambang emas dan lahan pertanian. Beberapa rumah petani berada di sini dilengkapi dengan sebuah toko.

\subsection{Kehidupan Budaya}

Kehidupan budaya Tionghoa nampak dalam berbagai segi kehidupan masyarakat Montrado. Perayaan/ upacara keagamaan besar yang secara berkala dilakukan oleh orang-orang di Montrado adalah Wong-ja- san dan Ceng-beng. Wong-ja-san merupakan perayaan yang didedikasikan untuk para pekerja tambang. Upacara ini adalah upacara pengorbanan untuk menghindarkan dari ketakutan terhadap setan atau hantu. Setiap orang yang tinggal di Montrado dapat ambil bagian pada perayaan ini. Perayaan dimulai dengan mengarak kertas-kertas pemujaan dan miniatur kapal dari klenteng pelindung menuju ke pusat kota (Rees, 1858: 65-66).. Sedangkan Ceng-beng merupakan peringatan sembahyang kubur untuk leluhur mereka.

Berkaitan dengan upacara di atas, orang Tionghoa menganggap bahwa kematian adalah sesuatu yang sakral dan harus dihormati. Oleh karena itu, perjamuan besar selalu dilakukan pada saat upacara kematian terutama untuk menjamu keluarga teman dan tetangga. Setelah itu mereka membaca doa-doa kematian dengan diterangi lilin-lilin. Setelah itu mereka akan membawa peti mati dalam keadaan tertutup menuju pemakaman dengan prosesi yang megah dan diiringi musik dari alat musik Tionghoa. Peti akan dimasukkan dalam lubang galian yang tidak begitu dalam di pemakaman yang terletak di atas bukit. Setelah peti dimasukkan dan ditutup dengan batu yang melingkar, makam kemudian diberi tanda dengan batu atau lempengan kayu besi (Rees, 1858: 68).

\subsection{Sanitasi dan Infrastruktur}

Pemeliharaan sanitasi merupakan hal yang penting bagi penduduk Montrado. Pada masa kejayaan, setiap tambang emas mampu mengeluarkan dana untuk kepentingan-kepentingan publik seperti membuat dan memelihara trotoar yang luas, membuat jembatan serta pemeliharaan dan pembersihan sungai (Engelhard, 1899: 244). Biaya untuk pemeliharaan jembatan dan tempat ibadah diambil dari berbagai macam pajak yang berlaku di tempat ini seperti, pajak dari rumah pemotongan hewan, tambang emas, 
rumah judi, pabrik arak dan rumah pegadaian (Rees, 1858: 77). ${ }^{14}$

Pusat kota Montrado memiliki pipa air yang mengalirkan air yang melimpah yang diambil dari Sungai Sjongbok. Pemerintah menempatkan petugas kesehatan (officier van gezondheid) kelas 2 untuk melakukan pelayanan kesehatan di sini (Rees, 1858: 39; Veth, 1869: 530). Nampaknya penguasa di Montrado sangat memperhatikan pendidikan warga. Lembaga pendidikan berupa sekolah jumlahnya banyak (Rees, 1858: 45). Hal ini terlihat dari adanya sekolah yang diperuntukkan bagi anak-anak laki-laki Tionghoa dan empat orang guru (Veth, 1869: 530; Heidhues, 2008: 58). Sarana dan prasarana kesehatan menunjukkan wilayah ini telah berkembang menjadi sebuah kota yang seimbang. Montrado memiliki tigapuluh tabib, limabelas ahli obat dan rumah perawatan kusta yang mempunyai 150 pasien (Heidhues, 2008: 58; Veth, 1869: 530). Veth menyebutkan bahwa terdapat beberapa rumah yang terlihat sedikit rapi dan biasanya rumahrumah tersebut dihuni oleh pembuat obat, tabib ataupun peramal (Veth, 1869: 530; Rees, 1858: 45). Seorang pembuat obat membuka praktek pengobatan. Kebutuhan akan hiburanpun dipenuhi dengan adanya duapuluh delapan rumah opium, sepuluh rumah judi dan dua restoran (Heidhues, 2008: 58).

Montrado sebagai pusat kegiatan kongsi merupakan sebuah kota yang dipertimbangkan oleh pemerintah Hindia Belanda. Keberadaan pegawai kolonial di kota yang juga merupakan ibukota dari Afdeeling Montrado pada waktu itu tentu saja berpengaruh pada penampakan fisik kota tersebut dengan berdirinya rumah controleur dan rumah asisten residen yang berupa bangunan kokoh dan luas dari kayu ulin dan memiliki perabot yang sangat praktis. Kebutuhan akan air terpenuhi

${ }^{14}$ Pendapatan dari pajak ini dianggap kurang mencukupi biaya pemeliharaan sehingga kemudian ada pajak yang dipungut dari setiap rumah tangga. dengan adanya aliran air dari sungai yang tidak jauh dari lahan pertanian (Buys, 1892: 174). Pada pertengahan abad ke-19 ini telah didirikan leprozerieen/leproserie (rumah perawatan penderita penyakit lepra/ kusta) di distrik Montrado (Veth,1869: 530). Di sisi lain kota ini terdapat sebuah penjara yang didirikan oleh pemerintah kolonial Belanda (Rees, 1858: 45).

Namun begitu, perubahan yang cukup drastis terlihat di Montrado memasuki tahun kedua paruh kedua abad ke-19. Akibat perang Kongsi 1851-1954 penduduk yang telah kehilangan pekerjaan karena dihapuskannya sistem kongsi diberatkan dengan biaya pemeliharaan jalan. Tahun 1853 tercatat orang Tionghoa dari berbagai kongsi melarikan diri ke Singkawang dan menjalankan pertanian di wilayah itu (Van Meteeren Brouwers, 1899: 1083). Mereka yang sebelumnya hanya memiliki keahlian di bidang pertambangan emas mulai berlatih bekerja di bidang pertanian. Awalnya mereka mengusahakan pertanian dengan bersawah dan kebun holtikultura namun secara bertahap mereka mulai mengusahakan budidaya kelapa yang pada awalnya diusahakan oleh orang-orang Bugis (Van Sandick, 1919: 52). Sekitar tahun 1890, pertanian di sekitar pusat kongsi yang diusahakan untuk mendukung kehidupan kongsi ditinggalkan lagi oleh pemiliknya. Gelombang kedua orang-orang Tionghoa dari kongsi mulai berpindah ke daerah pesisir. Sebagaimana telah disebutkan sebelumnya bahwa pertanian di Onderafdeeling Singkawang telah ada pada masa awal kedatangan Tionghoa di pertengahan abad ke-18 dan semakin bertambah pada pertengahan abad ke-19 akibat pertikaian kongsi dan terus meningkat pada akhir abad ke-19 akibat kebangkrutan kongsi. Mereka mengisi sudut-sudut Onderafdeeling Singkawang dengan pemukiman pertanian (Heidhues, 2008: 140).

Dari segi kependudukan, Montrado kehilangan sebagian besar penghuninya. 
Sejumlah besar penduduk memilih meninggalkan Montrado menuju pesisir pantai dan lembah-lembah sungai besar. Singkawang dan sekitarnya menjadi tujuan utama para pendatang dari bekas kongsi ini. Singkawang berkembang sebagai jalur utama perdagangan dengan Singapura yang pada saat itu menjadi pusat niaga internasional terutama perdagangan karet rakyat dan kelapa.

\section{PENUTUP}

Montrado berkembang menjadi salah satu pusat kongsi besar di wilayah Kerajaan Sambas pada akhir abad ke-19 sampai pertengahan abad ke-19. Walaupun Sultan Umar Akamuddin, yang sengaja mengundang mereka untuk mengelola lahan emas di wilayahnya, membatasi hakhak mereka pada pengelolaan tambang emas namun di sisi lain sultan memberikan kekuasaan pemerintahan, pengadilan dan keamanan pada kongsi-kongsi tersebut. Kongsi-kongsi kecil di wilayah tersebut kemudian bergabung dalam sebuah kongsi besar yang bernama Fosjoen. Setidaknya pada masa ini Sultan mendapatkan upeti dalam bentuk emas secara teratur. Keruntuhan kongsi merupakan eskalasi dari banyaknya konflik yang terjadi. Akar permasalahan adalah deposit emas yang semakin berkurang pada masing-masing kongsi sehingga terjadi perebutan lahan yang menyebabkan perpecahan antar kongsi. Dinamika konflik di wilayah yang dikuasai oleh kongsi Montrado menunjukkan empat bentuk-konflik yaitu (1) konflik antar kongsi, karena perebutan lahan (2) konflik kongsi dengan kongsi lain yang dibantu pemerintah kolonial (3) konflik kongsi dengan Dayak (4) konflik pasukan gabungan Kongsi Montrado dan Dayak dengan pasukan gabungan Dayak yang dikerahkan oleh pejabat kerajaan Sambas.

Kota Montrado masa kongsi menunjukkan gambaran kota yang lengkap dengann pusat pemerintahan, pusat perdagangan, sarana ibadah, kelengkapan infrastruktur dan sanitasi dan wilayah- wilayah pendukung. Ekologi kota ini berubah seiring dengan runtuhnya kongsi pertambangan emas yang berpusat di wilayah tersebut. Perubahan ini dapat dilihat dari berbagai sektor seperti penurunan jumlah penduduk akibat migrasi besar-besaran setelah perang serta regulasi yang menetapkan orang-orang Tionghoa di pedalaman untuk tinggal lebih dekat dengan pusat pemerintahan kolonial, runtuhnya simbol kekuasaan kongsi (thang) serta perubahan dalam organisasi pemerintahan sekaligus kemasyarakatan Tionghoa yang berganti dengan sistem yang ditetapkan pemerintah kolonial.

Kota dan masyarakat Montrado mengalami beberapa fase perubahan baik terkait dengan pengaruh aktivitas salah satu kongsi pertambangan emas besar yang menjadikannya sebagai pusat perekonomian maupun pengaruh aktivitas pemerintah kolonial yang di kemudian hari menjadikannya sebagai ibukota afdeeling sampai tahun 1880 .

\section{UCAPAN TERIMA KASIH}

Penulis mengucapkan terimakasih kepada rekan-rekan peneliti pada Balai Pelestarian Nilai Budaya Pontianak atas saran dan kritik dalam diskusinya dengan penulis.

\section{DAFTAR SUMBER}

\section{Arsip ANRI}

Statte Grond van Mondrato Koleksi ANRI

\section{Jurnal}

Engelhard, H.E.D.1899.

"Bijdragen tot Kennis van Het Grondbezit in de Chineesche Districten" dalam Bijdragen tot de Taal, Land en Volkenkunde van Nederlandsch-Indie.

\section{Buku}

Alqadrie, Syarif Ibrahim, Pandil Sastrowardoyo, 1984.

Sejarah Sosial Daerah Kotamadya Pontianak. Proyek Inventarisasi dan Dokumentasi Sejarah Nasional. Jakarta: Departemen Pendidikan dan Kebudayaan. 
Blusse', Leonard. 1988.

Persekutuan Aneh: Pemukim Cina, Wanita Peranakan dan Belanda di Batavia VOC. Seri Terjemahan KITLV-LIPI. Jakarta: Pustazet Perkasa.

Buys, M. 1892.

Twee Maanden op Borneo's Westkust. Leiden: S.C. van Doesburgh.

Dutch Borneo. 1920.

Handbooks prepared under the direction of the Historical Section of the Foreign Office. No. 84, H.M Stationery Office.

Earl, George Windsor. 1837.

The Eastern Seas. London: Wm. H. Allen and Co.

Encyclopaedie van Nederlandsch-Indie jilid I,1919 's-Gravenhage-Leiden Martinus Nijhoff, E.J. Brill.

Heidhues, Mary Somers. 2008. Penambang Emas, Petani dan Pedagang di "Distrik Tionghoa" Kalimantan Barat. Jakarta: Yayasan Nabil.

Kuntowijoyo. 2003.

Metodologi Sejarah. Edisi Kedua. Yogyakarta: PT Tiara Wacana Yogya.

Lontaan, J.U. 1975.

Sejarah dan Hukum Adat Kalimantan Barat. Jakarta: Departemen Pendidikan dan Kebudayaan.

Poerwanto, Hari. 2005.

Orang Cina Khek dari Singkawang. Depok: Komunitas Bambu.

Rahmayani, Any. 2010.

Permukiman Tionghoa di Singkawang Abad ke-19 (Sejarah Kota Bercirikan Tionghoa). Pontianak: BPSNT Pontianak. 2011.

Permukiman Tionghoa di Singkawang dan Sekitarnya. Dari Masa Kongsi Hingga Masa Kolonial (Abad ke-19 sampai Awal Abad ke-20). Pontianak: BPSNT Pontianak.

.Rees, W.A. van. 1858.

Montrado. Te Hertogenbosch: Gebr. Muller.

Veth, P.J. .ed, 1869.

Woorden Boek van Nederlansche Indie kq. Amsterdam: Tweede Deel. dialihbahasakan P Yeri, 2012.

Borneo Bagian Barat: Geografis, Statistis, Historis 1856. Pontianak: Institut Dayakologi.

Vleming Jr, J.L. 1926.

Het Chineesche Zakenleven in Nederlandsch-Indie. Door den BelastingAccountantsdienst in Nederlandsch-Indie. Uitgave Volkslectuur.

Wati, Arena. 1989.

Syair Perang Cina di Monterado. Bangi: Penerbit University Kebangsaan Malaysia.

\section{Majalah}

Sandick, J.C.F van \& Lt. Kolonel F.J. van Marle.

“Economische Geographie van Borneo's Wester-Afdeeling" (verslag eener Spoorwegverkenning in Noorwest Borneo en Dient der Staatsspoor en Tramwegen). Tijdschrift voor Economische Geographie 1919.

Meeteren Brouwer, P.M., van.

"De Geschiedenis der Chineesche Districten der Wester-Afdeeling van Borneo van 1740-1926". De Indische Gids 1926.

\section{Internet}

Erman, Erwiza. "Research Trends of Indonesian Mining History" diakses dari http://erwizaerman.com/papermakalah/Research-trends-of-indonesianmining-history/ pada 17 Agustus 2013. 